\title{
KESIAPAN PUSTAKAWAN DALAM MENGHADAPI ERA DIGITAL (Studi pada Pustakawan di Perpustakaan UGM)
}

\author{
Oleh: Wiyarsih* dan Maryatun**
}

\begin{abstract}
One of the characteristics of digital generation is having high dependence on the utilization of information technology and communication devices. This becomes a trigger for libraries to restructure the role and function of their existing resources, such as human resources that have vital position for the success of libraries in providing the services.

Libraries need librarians who have competency in the field of information technology to synergize with users. In reality, the librarians are still dominated by the librarians from the digital immigrant generation who are still learning to adapt with the new environments in information technology. Therefore, the readiness of librarians to meet the needs of digital generation becomes the main issue in this study.

This was a descriptive study with qualitative approach. The study objects were the librarians in Gadjah Mada University. The samples (informants) of librarians were those who represented digital immigrant generation and digital generation. Data gathering methods in this study were literature, in-depth interviews, and observation. The data analysis applied was qualitative analysis and data validity examination using triangulation.

Based on the result, it can be concluded that from several aspects of librarians' competency in Technology (Competencies Technology: Core Skills), which includes Core E-mail, Core Hardware, Core Internet, Core Operating Systems, Core Software, Core Web Tool and Technology Competencies (Systems \& IT), librarians of digital generation have better competency than librarians of digital immigrant generation in the field of IT. Therefore, librarians of digital generation are better prepared to face users of digital generation. However, librarians of digital immigrant generation still have passion or motivation to learn in the field of technology to meet the demanding needs users of digital generation.
\end{abstract}

Keywords: competency, librarians, digital generation, technology, digital immigrants

* Pustakawan UGM ditugaskan di Perpustakaan Fakultas MIPA UGM

** Pustakawan UGM ditugaskan di Perpustakaan Fakultas Ekonomi \& Bisnis UGM (DIII/Sekolah Vokasi)

\section{A. Pendahuluan}

Perkembangan ilmu pengetahuan dan teknologi pada saat ini sudah begitu pesat dan mempengaruhi berbagai segi kehidupan, salah satunya adalah perubahan gaya hidup manusia. Gaya hidup generasi pada era saat ini berbeda dengan gaya hidup generasi sebelumnya. Perbedaan yang mencolok adalah bahwa generasi era saat ini sangat akrab dengan teknologi, sedangkan generasi sebelumnya biasanya masih belajar untuk beradaptasi dengan perkembangan teknologi informasi.

Generasi era saat ini yang sering disebut sebagai generasi digital merupakan generasi yang lahir pada saat perkembangan teknologi informasi yang begitu pesat. Dengan demikian generasi ini sangat akrab dan bahkan mempunyai ketergantungan yang tinggi dengan gadget atau peralatan komunikasi. Menurut Mardianto (2010) generasi digital memiliki naluri alamiah yang dapat dengan mudah mencari berbagai informasi, belajar dan memecahkan masalahnya sendiri, serta menciptakan berbagai inovasi kreatif dengan segala pernak-pernik teknologi.

Pada saat ini pustakawan di UGM masih didominasi oleh pustakawan generasi digital immigrant, yaitu generasi yang lahir sebelum era teknologi informasi. Menurut Evilyn (2010), digital immigrant ini masih belajar untuk beradaptasi dengan lingkungan baru, namun tetap memelihara beberapa hal dari lingkungan masa lalu, walaupun ada beberapa digital immigrant yang mampu beradaptasi dengan sempurna dalam dunia teknologi informasi. Hal ini merupakan tantangan besar bagi pustakawan di UGM dalam memenuhi kebutuhan pemustaka.

Apabila pustakawan tidak mampu beradaptasi dengan kebutuhan pemustaka yang sebagian besar adalah generasi digital, maka tentu perpustakaan akan 
ditinggalkan oleh pemustaka. Mereka akan mencari informasi ke tempat lain yang lebih menawarkan kecanggihan dan kemudahan dalam mengakses informasi. Oleh sebab itu perpustakaan memerlukan pustakawan yang memiliki kompetensi dalam bidang teknologi informasi agar dapat memberikan layanan yang memuaskan (customer satisfaction) bagi generasi digital. Untuk itu penulis tertarik untuk meneliti sejauh mana kesiapan pustakawan di era digital dan bagaimana perbedaan kompetensi antara pustakawan generasi digital immigrant dan pustakawan generasi digital di bidang teknologi.

\section{B. Tinjauan Pustaka}

Pada era digital ini pemustaka lebih banyak didominasi oleh generasi digital yang cerdas dalam menggunakan peralatan teknologi informasi. Oleh karena itu pustakawan dituntut mampu menyesuaikan dengan karekteristik dari pemustaka dari generasi digital yang membutuhkan pelayanan yang cepat, tepat dan akurat. Untuk dapat mengikuti kebutuhan pemustaka dari generasi digital maka pustakawan harus mempunyai kompetensi di bidang teknologi.

Hampir semua kegiatan operasional perpustakaan dan pelayanan sudah menggunakan peralatan teknologi modern. Oleh sebab itu pustakawan UGM dituntut memiliki kompetensi teknologi informasi agar dapat memberikan kontribusi yang optimal dalam memberikan pelayanan kepada pemustaka, mengingat pemustaka potensial di Perpustakaan UGM adalah generasi yang user-friendly dengan teknologi. Sementara itu, sebagian besar pustakawan UGM merupakan generasi digital immigrant.

Pustakawan memerlukan kompetensi dasar di bidang teknologi informasi yang meliputi kemampuan dalam menggunakan e-mail, hardware, internet, operating systems, software applications, dan web tools. Kemampuan tersebut perlu dimiliki oleh pustakawan agar tidak tertinggal atau ditinggalkan pemustaka.

Federal Libray \& Information Center Committee Library of Congress mendefinisikan kompetensi sebagai pengetahuan, keterampilan, dan kemampuan yang ditetapkan dan disumbangkan untuk kinerja dalam profesi tertentu. Kompetensi dapat diamati, diukur dan diperingkat. Sedangkan Rivai (2009) merumuskan bahwa kompetensi diartikan sebagai kemampuan seseorang yang dapat terobservasi yang mencakup pengetahuan, keterampilan, dan sikap dalam menyelesaikan suatu pekerjaan sesuai dengan perform yang ditetapkan.
Dari dua definisi tersebut di atas dapat dirumuskan bahwa kompetensi adalah kemampuan yang dimiliki seseorang pada profesi tertentu berupa pengetahuan, keterampilan dan sikap dalam menyelesaikan pekerjaan.

Menurut WebJunction (2009), perkembangan teknologi telah menyebar di semua level termasuk dalam kegiatan pelayanan dan operasional perpustakaan. Semua posisi mensyaratkan kegiatannya dengan bantuan komputer. Kompetensi pustakawan yang disyaratkan dalam bidang teknologi sebagai keterampilan dasarnya berupa kemampuan dalam menggunakan e-mail, hardware, internet, operating systems, software applications, dan web tools.

Penggunaan e-mail bermanfaat ketika pemustaka membutuhkan informasi maka pustakawan langsung dapat mengirim informasi yang dibutuhkan hanya dalam hitungan menit bahkan detik.

Pustakawan dalam menggunakan hardware dan komponennya harus disertai pengetahuan bagaimana alat tersebut dapat berfungsi sehingga apabila ada trouble dapat mengatasinya.

Internet dan World Wide Web memudahkan pustakawan dalam melakukan penelusuran informasi yang relevan dan akurat dengan kebutuhan pemustaka. Pustakawan juga dapat melakukan download subyeksubyek dari e-book atau e-journal yang sering dicari oleh pemustaka. Menurut Sukirno (2004), adanya internet telah membongkar bangunan informasi yang terlalu kokoh dan susah untuk diakses menjadi sangat mudah dan murah untuk diakses.

Fungsi sistem operasi dasar berhubungan dengan cara mengelola file atau folder yang ada, mengecek virus, delete, dan fungsi recycle bin dapat membantu pustakawan dalam mengelola informasi.

Software application, seperti word processing operations, mengidentifikasi printer dalam sebuah jaringan membantu pustakawan dalam pembuatan dokumen perpustakaan, seperti pembuatan kartu bebas pustaka, surat pengantar, dan sebagainya.

Penggunakan fasilitas/peralatan yang berfungsi sebagai social networking seperti Facebook, YouTube, MySpace, Flickr, Blog, webconference mampu mendekatkan perpustakaan dengan pemustaka. Optimalnya fungsi social networking akan mengubah paradigma lama perpustakaan sebagai tempat menyimpan buku menjadi paradigma baru yaitu perpustakaan sebagai pusat informasi. 


\section{Metode Penelitian}

Penelitian ini merupakan penelitian deskriptif dengan pendekatan kualitatif dengan maksud untuk mengetahui sejauh mana kesiapan pustakawan di UGM dalam menghadapi era digital. Sampel pada penelitian ini adalah sampel bertujuan (purposive sample). Sampel (informan) dalam penelitian ini adalah pustakawan yang mewakili generasi digital immigrant dan generasi digital. Teknik pengumpulan data yang digunakan dalam penelitian ini adalah dengan studi pustaka, melakukan wawancara mendalam (indepth interview) dengan menggunakan panduan wawancara (interview guide) dan observasi (pengamatan langsung). Variabel yang akan dianalisis adalah kompetensi pustakawan yang berkaitan dengan teknologi hasil kompilasi WebJunction (2009), yang mencakup kemampuan dalam menggunakan e-mail, hardware, internet, operating systems, software applications, dan web tools.

Adapun langkah-langkah analisis data yang digunakan dalam penelitian ini adalah menurut Nasution (2003: 129) yakni (1) reduksi data, (2) "display" data, (3) mengambil kesimpulan dan verifikasi.

\section{Hasil dan Pembahasan}

Berdasarkan hasil penelitian yang pernah kami lakukan terhadap kesiapan pustakawan di UGM dalam menghadapi era digital, maka dapat diketahui bahwa kompetensi pustakawan di UGM dalam bidang teknologi informasi adalah sebagai berikut:

\section{a. Core E-Mail}

Dalam hal kompetensi e-mail, semua pustakawan menggunakan aplikasi e-mail berbasis web karena adanya beberapa kekurangan dari aplikasi berbasis desktop. Disamping itu memang karena belum mengetahui tentang aplikasi e-mail yang berbasis desktop. Aplikasi e-mail yang berbasis web mempunyai keuntungan mudah dibuka di mana-mana di terminal komputer yang terhubung oleh jaringan internet, sedangkan aplikasi e-mail yang berbasis desktop hanya dapat dibuka pada satu komputer tertentu.

Semua pustakawan menggunakan lebih dari satu nama domain dalam mengunakan e-mail, misalnya yahoo.com, ugm.ac.id dan gmail. Hal ini disesuaikan dengan kebutuhan atau kegiatan. Untuk kegiatan yang bersifat resmi, pada umumnya pustakawan menggunakan alamat e-mail ugm.ac.id, walaupun pustakawan mengeluhkan adanya keterbatasan kapasitas dan banyak muncul spam. Alamat e-mail yahoo.com dan gmail digunakan untuk kegiatan nonformal.

Pada umumnya pustakawan sudah dapat melakukan fungsi dasar dari aplikasi e-mail seperti, menerima, membuka, mengirim, atau menghapus pesan e-mail. Pada umumnya pustakawan menggunakan $e$-mail untuk mendukung tugas-tugas yang berhubungan dengan pekerjaannya dan untuk berkomunikasi dengan teman, namun pustakawan generasi digital menggunakan e-mail untuk kegiatan yang lebih kompleks atau bervariasi, seperti untuk tukar-menukar dokumen, kolaborasi dengan temanteman, korespondensi, mendaftar aplikasi, mailing list, koordinasi, langganan jurnal, pengadaan buku dan sebagainya.

Pustakawan generasi digital sudah mengelola $e$ mail seperti mengelola spam, membuat folder-folder dan menghapus kiriman e-mail yang tidak berguna. Pustakawan generasi digital immigrant belum mengelola e-mail-nya dalam bentuk folder-folder, baru mengelola e-mail dengan menghapus kiriman $e$ mail yang tidak berguna.

\section{b. Core Hardware}

Dalam bidang hardware, pada umumnya pustakawan sudah memahami dan dapat menggunakan berbagai hardware yang tersedia di perpustakaan untuk mendukung tugas-tugasnya. Mereka mampu menyebutkan hardware apa saja yang tersedia di perpustakaan seperti komputer, printer, scanner, barcode reader serta fungsi masing-masing hardware tersebut. Scanner sudah dimanfaatkan oleh pustakawan untuk mengalihmediakan koleksi agar informasi dapat diakses lebih cepat. Mereka juga mengenal perangkat untuk menyimpan data karena mereka biasanya melakukan backup data di berbagai perangkat penyimpanan data seperti hardisk, USB, DVD, hardisk eksternal dan server.

Apabila terjadi troubleshooting ringan pada hardware, pada umumnya pustakawan dapat mengatasinya, misalnya terjadi paper jam, menghilangkan virus, instal ulang, cek jaringan dan sebagainya, tetapi pustakawan generasi digital mampu mengatasi masalah yang lebih sulit, seperti dalam menangani spare part hardware yang rusak. Semua Pustakawan berusaha mengatasi trouble sendiri dan apabila sudah tidak dapat mengatasi, baru menanyakan pada tim TI di lembaganya. 


\section{c. Core Internet}

Pustakawan mengerti dan dapat menggunakan internet dan World Wide Web, namun untuk pustakawan generasi digital lebih variatif dan aktif dalam menggunakan internet dari pada pustakawan generasi digital immigrant. Pustakawan generasi digital selain menggunakan internet untuk kegiatan yang berhubungan dengan pekerjaannya juga untuk hiburan pada waktu senggang, misalnya bermain game, akses YouTube, mendengarkan musik, dan untuk jejaring sosial seperti chating, facebook, dan sebagainya. Pustakawan generasi digital immigrant menggunakan internet untuk melakukan kegiatan yang berhubungan dengan pekerjaannya dan jarang untuk kegiatan yang bersifat hiburan ataupun untuk jejaring sosial.

Pustakawan sudah memanfaatkan internet untuk proses pengadaan koleksi, misalnya untuk mengirim daftar pesanan buku atau jurnal ke toko buku atau penerbit. Internet juga digunakan oleh pustakawan sebagai sarana untuk menelusur informasi. Mereka membuka suatu website menggunakan fungsi dari web browser (scroll, bookmark, history) atau dengan mengetikkan"alamat website. Website yang sering dibuka adalah yang mendukung kegiatan perpustakaan, namun untuk pustakawan generasi digital lebih banyak alamat website yang dikunjungi daripada pustakawan generasi digital immigrant. Selain mengunjungi website yang berhubungan dengan pekerjaannya, pustakawan juga mengunjungi website yang memuat informasi-informasi terbaru.

Pustakawan juga mampu melakukan penelusuran informasi yang dibutuhkan oleh pemustaka, baik berdasarkan permintaan maupun informasi yang memang perlu diketahui oleh pemustaka sehingga pustakawan merasa perlu untuk melakukan penelusuran informasi. Informasi tersebut terutama yang berkaitan dengan subyek ilmu untuk mendukung proses belajar mengajar. Cara melakukan penelusuran informasi dengan browsing ke web site yang relevan dengan pertanyaan yang diajukan pemustaka. Pustakawan melakukan penelusuran informasi dengan berbagai strategi misalnya melalui subyek, kata kunci, judul, pengarang, dan apabila tidak bisa baru memakai bolean.

Pustakawan sudah mampu melakukan akses $e$ jurnal dan e-book, baik yang dilanggan oleh lembaganya maupun oleh UPU Perpustakaan UGM untuk memenuhi permintaan pemustaka. Apabila database yang dilanggan lembaganya belum bisa mencukupi kebutuhan pemustaka, pustakawan tetap berupaya untuk mencarikan ke sumber lain. Secara umum file yang didownload berupa teks dari $e$-book, $e$ journal atau artikel dari suatu web site. Pustakawan jarang mendownload gambar, film, rekaman suara/video karena membutuhkan waktu yang lama, sehingga akan mempengaruhi kecepatan kerja sebuah jaringan.

Pustakawan juga bisa mengatasi gangguan yang berupa virus maupun pop-up. Untuk mengatasi virus pada komputer, para pustakawan memanfaatkan antivirus yang di-install pada komputer yang selalu dapat di-update secara otomatis apabila terhubung dengan jaringan internet. Ada pustakawan yang sudah memanfaatkan open source, yaitu program linux, sehingga ia merasa tidak khawatir dengan masalah virus. Pustakawan menangani munculnya pop-up yang berupa pesan iklan yang muncul pada saat melakukan akses informasi dengan cara menutup pesan tersebut apabila mengganggu atau membacanya dahulu apabila pesan itu penting. Ada juga pustakawan yang menggunakan program untuk memblokir pop-up.

Kebijakan perpustakaan dalam menggunakan internet bagi pemusaka sudah longgar. Pustakawan hanya mengingatkan apabila terjadi antrian atau ada yang download film karena dapat memperlambat kecepatan akses pemustaka yang lain. Kelonggaran peraturan tersebut berkaitan dengan semakin banyaknya pemustaka yang membawa laptop sendiri ketika datang ke perpustakaan.

\section{d. Core Operating Systems}

Dalam bidang operating systems, pustakawan sudah memahami dan dapat menjalankan fungsi sistem operasi dasar seperti, membuka dan menutup sistem operasi, membuka program dari menu utama atau dari desktop, dan mengenal ekstensi file-file umum. File-file yang ada di hardisk atau file yang disimpan pada media lain sudah dikelola dengan baik. Mereka sudah mengelola file dan folder sesuai dengan kepentingan atau kegiatannya sehingga mudah ditemukan kembali. Pustakawan memelihara sistem operasi agar dapat berjalan secara optimal dengan cara menghapus file-file yang tidak digunakan ke dalam recycle bin dan menjalankan program antivirus secara teratur.

\section{e. Core Software}

Pada umumnya pustakawan sudah memahami dan dapat melakukan fungsi dasar dari aplikasi software, terutama yang berkaitan dengan otomasi perpustakaan. Aplikasi software lain yang juga digunakan adalah Microsoft Office for Window yang 
meliputi MsAccess, MsExcel, MsPowerPoint, MsPublisher dan MsWord. Pustakawan generasi digital memiliki kemampuan dalam memahami dan menjalankan aplikasi software lain seperti $\dot{A} d o b e$ Acrobat, CorelDraw, Open Office (Linux).

Apabila terjadi troubleshooting dengan aplikasi software yang digunakan, pustakawan generasi digital mencoba memperbaiki sendiri dan jika tidak dapat maka diserahkan ke tim TI. Pada umumnya pustakawan generasi digital immigrant apabila ada masalah dengan aplikasi software maka langsung diserahkan ke tim TI.

\section{f. Core Web Tools}

Pustakawan telah mengerti dan dapat menggunakan alat-alat jejaring sosial dan kolaborasi secara online seperti facebook, blog, twiter dan chatting, tetapi sebagian besar pustakawan tidak menggunakan Feed dan RSS serta jarang menggunakan photo-sharing. Pustakawan generasi digital mempunyai blog walaupun jarang di-update dan juga aktif menggunakan facebook. Sebagian besar pustakawan generasi digital immigrant belum mempunyai blog dan jarang menggunakan facebook.

Pustakawan juga sudah menggunakan filesharing, tetapi untuk pustakawan generasi digital sebagian sudah menggunakan web khusus dalam melakukan file-sharing, sedang pustakawan generasi digital immigrant masih menggunakan e-mail untuk file-sharing. Selain itu, pustakawan mengetahui tentang web conference, tetapi untuk pustakawan generasi digital sebagian pernah menggunakannya dan mengetahui secara teknis agar web conference dapat berfungsi dengan baik. Pustakawan juga menggunakan menu bantuan, tutorial dan blog dari komunitas untuk memperoleh keterampilan. Selain itu pustakawan juga mengikuti sumber-sumber informasi dan teknologi baru misalnya dari detik.com, kompas.com dan yahoo.com.

Dari hasil analisis tentang kesiapan pustakawan dalam menghadapi era digital di atas, maka untuk lebih jelasnya dapat dilihat pada tabel dibawah ini:

\section{A. Core E-mail}

\begin{tabular}{|c|c|c|}
\hline NO. & $\begin{array}{l}\text { PUSTAKAWAN } \\
\text { GENERASI } \\
\text { DIGITAL } \\
\text { IMMIGRANT }\end{array}$ & $\begin{array}{l}\text { PUSTAKAWAN } \\
\text { GENERASI } \\
\text { DIGITAL }\end{array}$ \\
\hline 1 & $\begin{array}{l}\text { Mampu melakukan } \\
\text { fungsi dasar e-mail. }\end{array}$ & $\begin{array}{l}\text { Mampu melakukan } \\
\text { fungsi dasar } e \text {-mail. }\end{array}$ \\
\hline 2 & $\begin{array}{l}\text { Menggunakan e- } \\
\text { mail berbasis web }\end{array}$ & $\begin{array}{l}\text { Menggunakan } e- \\
\text { mail berbasis web }\end{array}$ \\
\hline 3 & $\begin{array}{l}\text { Menggunakan lebih } \\
\text { dari satu nama } \\
\text { domain }\end{array}$ & $\begin{array}{l}\text { Menggunakan lebih } \\
\text { dari satu nama } \\
\text { domain }\end{array}$ \\
\hline 4 & $\begin{array}{l}E \text {-mail terutama } \\
\text { digunakan untuk } \\
\text { mendukung tugas }\end{array}$ & $\begin{array}{l}\text { Penggunaannya } \\
\text { lebih bervariasi }\end{array}$ \\
\hline 5 & $\begin{array}{l}\text { Mengelola e-mail } \\
\text { dengan menghapus } \\
\text { kiriman e-mail } \\
\text { yang sudah tidak } \\
\text { berguna, tetapi } \\
\text { belum mengelola } e- \\
\text { mail dalam bentuk } \\
\text { folder. }\end{array}$ & $\begin{array}{l}\text { Mengelola } e \text {-mail } \\
\text { dengan menghapus } \\
\text { kiriman e-mail } \\
\text { yang tidak berguna } \\
\text { dan mengelolanya } \\
\text { dalam bentuk } \\
\text { folder }\end{array}$ \\
\hline 6 & $\begin{array}{l}\text { Belum mengelola } \\
\text { spam }\end{array}$ & $\begin{array}{l}\text { Ada beberapa yang } \\
\text { sudah mengelola } \\
\text { spam }\end{array}$ \\
\hline
\end{tabular}

\section{B. Core Hardware}

\begin{tabular}{|l|l|l|}
\hline NO. & $\begin{array}{l}\text { PUSTAKAWAN } \\
\text { GENERASI } \\
\text { DIGITAL } \\
\text { IMMIGRANT }\end{array}$ & $\begin{array}{c}\text { PUSTAKAWAN } \\
\text { GENERASI } \\
\text { DIGITAL }\end{array}$ \\
\hline 1 & $\begin{array}{l}\text { Mampu } \\
\text { menyebutkan } \\
\text { macam-macam } \\
\text { hardware yang ada } \\
\text { di Perpustakaan }\end{array}$ & $\begin{array}{l}\text { Mampu } \\
\text { menyebutkan } \\
\text { macam-macam } \\
\text { hardware yang ada } \\
\text { di perpustakaan }\end{array}$ \\
\hline 2 & $\begin{array}{l}\text { Mampu mengatasi } \\
\text { masalah ringan } \\
\text { pada hardware }\end{array}$ & $\begin{array}{l}\text { Mampu mengatasi } \\
\text { masalah yang lebih } \\
\text { sulit }\end{array}$ \\
\hline 3 & $\begin{array}{l}\text { Bila ada masalah } \\
\text { berusaha mengatasi } \\
\text { sendiri sebelum } \\
\text { menanyakan ke } \\
\text { tim TI }\end{array}$ & $\begin{array}{l}\text { Bila ada masalah } \\
\text { berusaha men gatasi } \\
\text { sendiri sebelum } \\
\text { menanyakan ke tim } \\
\text { TI }\end{array}$ \\
\hline
\end{tabular}




\section{Core Internet}

\begin{tabular}{|c|c|c|}
\hline NO. & $\begin{array}{c}\text { PUSTAKAWAN } \\
\text { GENERASI } \\
\text { DIGITAL } \\
\text { IMMIGRANT }\end{array}$ & $\begin{array}{c}\text { PUSTAKAWAN } \\
\text { GENERASI } \\
\text { DIGITAL }\end{array}$ \\
\hline 1 & $\begin{array}{l}\text { Mengerti dan dapat } \\
\text { menggunakan } \\
\text { internet }\end{array}$ & $\begin{array}{l}\text { Mengerti dan dapat } \\
\text { menggunakan } \\
\text { internet }\end{array}$ \\
\hline 2 & $\begin{array}{l}\text { Menggunakan } \\
\text { internet untuk } \\
\text { mendukung } \\
\text { tugasnya tetapi } \\
\text { jarang untuk } \\
\text { hiburan maupun } \\
\text { jejaring sosial }\end{array}$ & $\begin{array}{l}\text { Menggunakan } \\
\text { internet untuk } \\
\text { mendukung tugas } \\
\text { dan untuk hiburan } \\
\text { dan jejaring sosial } \\
\text { di waktu senggang }\end{array}$ \\
\hline 3 & $\begin{array}{l}\text { Website yang } \\
\text { dikunjungi hanya } \\
\text { tertentu }\end{array}$ & $\begin{array}{l}\text { Website yang } \\
\text { dikunjungi lebih } \\
\text { banyak }\end{array}$ \\
\hline 4 & $\begin{array}{l}\text { Melakukan } \\
\text { penelusuran } \\
\text { informasi sesuai } \\
\text { kebutuhan } \\
\text { pemustaka }\end{array}$ & $\begin{array}{l}\text { Melakukan } \\
\text { penelusuran } \\
\text { informasi sesuai } \\
\text { kebutuhan } \\
\text { pemustaka }\end{array}$ \\
\hline 5 & $\begin{array}{l}\text { Pustakawan } \\
\text { mampu melakukan } \\
\text { penelusuran } \\
\text { informasi yang } \\
\text { dibutuhkan oleh } \\
\text { pemustaka }\end{array}$ & $\begin{array}{l}\text { Pustakawan } \\
\text { mampu melakukan } \\
\text { penelusuran } \\
\text { informasi yang } \\
\text { dibutuhkan oleh } \\
\text { pemustaka }\end{array}$ \\
\hline 6 & $\begin{array}{l}\text { Mampu melakukan } \\
\text { akses e-journal dan } \\
e \text {-book yang } \\
\text { dilanggan oleh } \\
\text { lembaganya } \\
\text { maupun website } \\
\text { yang dilanggan } \\
\text { UPT Perpustakaan } \\
\text { UGM }\end{array}$ & $\begin{array}{l}\text { Mampu melakukan } \\
\text { akses e-journal dan } \\
\text { e-book yang } \\
\text { dilanggan oleh } \\
\text { lembaganya } \\
\text { maupun website } \\
\text { yang dilanggan } \\
\text { UPT Perpustakaan } \\
\text { UGM }\end{array}$ \\
\hline 7 & $\begin{array}{l}\text { Mampu melakukan } \\
\text { download e-journal } \\
\text { dan e-book. Secara } \\
\text { umum file yang di- } \\
\text { download berupa } \\
\text { teks }\end{array}$ & $\begin{array}{l}\text { Mampu melakukan } \\
\text { download e-journal } \\
\text { dan e-book. Secara } \\
\text { umum file yang di- } \\
\text { download berupa } \\
\text { teks }\end{array}$ \\
\hline 8 & $\begin{array}{l}\text { Bisa mengatasi } \\
\text { gangguan yang } \\
\text { berupa virus } \\
\text { maupun pop-up. }\end{array}$ & $\begin{array}{l}\text { Bisa mengatasi } \\
\text { gangguan yang } \\
\text { berupa virus } \\
\text { maupun pop-up. }\end{array}$ \\
\hline
\end{tabular}

\begin{tabular}{|l|l|l|}
\hline 9 & $\begin{array}{l}\text { Memanfaatkan } \\
\text { antivirus, dan } \\
\text { sebagian ada yang } \\
\text { menggunakan } \\
\text { sistem open source } \\
\text { sehingga tidak ada } \\
\text { masalah dengan } \\
\text { virus }\end{array}$ & $\begin{array}{l}\text { Memanfaatkan } \\
\text { antivirus dan } \\
\text { sebagian ada yang } \\
\text { menggunakan } \\
\text { sistem open source } \\
\text { sehingga tidak ada } \\
\text { masalah dengan } \\
\text { virus }\end{array}$ \\
\hline 10 & $\begin{array}{l}\text { Kebijakan } \\
\text { penggunaan } \\
\text { internet longgar }\end{array}$ & $\begin{array}{l}\text { Kebijakan } \\
\text { penggunaan } \\
\text { internet longgar }\end{array}$ \\
\hline 11 & $\begin{array}{l}\text { Sebagian sudah } \\
\text { memanfaatkan } \\
\text { internet dalam } \\
\text { proses pengadaan } \\
\text { koleksi }\end{array}$ & $\begin{array}{l}\text { Sebagian sudah } \\
\text { memanfaatkan } \\
\text { internet dalam } \\
\text { proses pengadaan } \\
\text { koleksi }\end{array}$ \\
\hline
\end{tabular}

\section{Core Operating Systems}

\begin{tabular}{|c|c|c|}
\hline NO. & $\begin{array}{l}\text { PUSTAKAWAN } \\
\text { GENERASI } \\
\text { DIGITAL } \\
\text { IMMIGRANT }\end{array}$ & $\begin{array}{l}\text { PUSTAKAWAN } \\
\text { GENERASI } \\
\text { DIGITAL }\end{array}$ \\
\hline 1 & $\begin{array}{l}\text { Mampu melakukan } \\
\text { dan menjelaskan } \\
\text { fungsi sistem } \\
\text { operasi dasar }\end{array}$ & $\begin{array}{l}\text { Mampu melakukan } \\
\text { dan menjelaskan } \\
\text { fungsi sistem } \\
\text { operasi dasar }\end{array}$ \\
\hline 2 & $\begin{array}{l}\text { Sudah mampu } \\
\text { mengelola file dan } \\
\text { folder }\end{array}$ & $\begin{array}{l}\text { Sudah mampu } \\
\text { mengelola file dan } \\
\text { folder }\end{array}$ \\
\hline 3 & $\begin{array}{l}\text { Mampu } \\
\text { memelihara sistem } \\
\text { operasi }\end{array}$ & $\begin{array}{l}\text { Mampu } \\
\text { memelihara sistem } \\
\text { operasi }\end{array}$ \\
\hline
\end{tabular}

\section{E. Core Software}

\begin{tabular}{|l|l|l|}
\hline NO. & $\begin{array}{l}\text { PUSTAKAWAN } \\
\text { GENERASI } \\
\text { DIGITAL } \\
\text { IMMIGRANT }\end{array}$ & \multicolumn{1}{c|}{$\begin{array}{c}\text { PUSTAKAWAN } \\
\text { GENERASI } \\
\text { DIGITAL }\end{array}$} \\
\hline 1 & $\begin{array}{l}\text { Mampu melakukan } \\
\text { fungsi dasar } \\
\text { aplikasi software }\end{array}$ & $\begin{array}{l}\text { Mampu melakukan } \\
\text { fungsi dasar } \\
\text { aplikasi software }\end{array}$ \\
\hline 2 & $\begin{array}{l}\text { Menggunakan } \\
\text { aplikasi software } \\
\text { tertentu }\end{array}$ & $\begin{array}{l}\text { Lebih banyak } \\
\text { menggunakan } \\
\text { aplikasi software }\end{array}$ \\
\hline 3 & $\begin{array}{l}\text { Apabila ada } \\
\text { masalah dengan } \\
\text { aplikasi software } \\
\text { maka langsung } \\
\text { diserahkan ke tim } \\
\text { TI }\end{array}$ & $\begin{array}{l}\text { Apabila ada } \\
\text { masalah mencoba } \\
\text { memperbaiki } \\
\text { sendiri dulu, dan } \\
\text { apabila tidak bisa } \\
\text { baru diserahkan ke } \\
\text { tim TI. }\end{array}$ \\
\hline
\end{tabular}

24 Berkala IImu Perpustakaan dan Informasi - Volume VIII Nomor 1, 2012 


\section{F. Core Web Tools}

\begin{tabular}{|l|l|l|}
\hline No & $\begin{array}{c}\text { PUSTAKAWAN } \\
\text { GENERASI } \\
\text { DIGITAL } \\
\text { IMIGRANT }\end{array}$ & $\begin{array}{l}\text { PUSTAKAWAN } \\
\text { GENERASI } \\
\text { DIGITAL }\end{array}$ \\
\hline 1 & $\begin{array}{l}\text { Sebagian besar belum } \\
\text { mempunyai blog }\end{array}$ & $\begin{array}{l}\text { Mempunyai blog } \\
\text { tetapi jarang di - } \\
\text { update }\end{array}$ \\
\hline 2 & $\begin{array}{l}\text { Jarang menggunakan } \\
\text { facebook }\end{array}$ & $\begin{array}{l}\text { Aktif } \\
\text { menggunakan } \\
\text { facebook }\end{array}$ \\
\hline 3 & $\begin{array}{l}\text { Sebagian besar tidak } \\
\text { menggunakan Feed } \\
\text { dan RSS }\end{array}$ & $\begin{array}{l}\text { Sebagian besar } \\
\text { tidak } \\
\text { menggunakan } \\
\text { Feed dan } \text { RSS }\end{array}$ \\
\hline 4 & $\begin{array}{l}\text { Menggunakan file } \\
\text { sharing dengan } \\
\text { mail }\end{array}$ & $\begin{array}{l}\text { Sebagian } \\
\text { menggunakan file } \\
\text { sharing dengan } \\
\text { web khusus }\end{array}$ \\
\hline 5 & $\begin{array}{l}\text { Jarang menggunakan } \\
\text { photosharing }\end{array}$ & $\begin{array}{l}\text { Jarang } \\
\text { menggunakan } \\
\text { photosharing }\end{array}$ \\
\hline 6 & $\begin{array}{l}\text { Mengetahui tentang } \\
\text { web conference }\end{array}$ & $\begin{array}{l}\text { Sebagian pernah } \\
\text { menggunakan web } \\
\text { conference dan } \\
\text { mengetahui secara } \\
\text { teknis }\end{array}$ \\
\hline 7 & $\begin{array}{l}\text { Menggunakan menu } \\
\text { bantuan tutorial dan } \\
\text { mengikuti sumber - } \\
\text { baru informasi }\end{array}$ & $\begin{array}{l}\text { Menggunakan } \\
\text { menu bantuan } \\
\text { tutorial dan blog } \\
\text { komunitas serta } \\
\text { mengikuti } \\
\text { sumber-sumber } \\
\text { informasi baru }\end{array}$ \\
\hline
\end{tabular}

\begin{tabular}{|c|c|c|}
\hline 4 & $\begin{array}{l}\text { Belum mampu } \\
\text { melakukan install, } \\
\text { konfigurasi dan } \\
\text { pemeliharaan } \\
\text { hardware }\end{array}$ & $\begin{array}{l}\text { Beberapa } \\
\text { pustakawan mampu } \\
\text { melakukan install, } \\
\text { konfigurasi dan } \\
\text { pemeliharaan } \\
\text { hardware } \\
\text { perpustakaan } \\
\text { dengan bantuan tim }\end{array}$ \\
\hline
\end{tabular}

\section{E. Kesimpulan}

Berdasarkan pembahasan di atas, maka dapat diketahui bahwa dari beberapa aspek kompetensi pustakawan di bidang TI yang meliputi Core E-mail, Core Hardware, Core Internet, Core Operating Systems, Core Software, Core Web Tools, dan Core Technology: System dan Technology Information, pustakawan generasi digital mempunyai kompetensi di bidang teknologi yang lebih dari pada pustakawan generasi digital immigrant. Beberapa kelebihan kompetensi teknologi dari pustakawan generasi digital dibandingkan generasi digital immigrant adalah sebagai berikut:

\section{Core E-mail}

Pustakawan generasi digital lebih bervariasi dalam menggunakan e-mail dari pada pustakawan generasi digital immigrant. Pustakawan generasi digital menggunakan e-mail selain untuk mendukung tugas-tugas juga untuk kegiatan lain seperti tukar-menukar dokumen, kolaborasi dengan teman-teman, korespondensi, mendaftar aplikasi, mailing list, koordinasi, langganan jurnal, pengadaan buku dan sebagainya.

Pustakawan generasi digital sudah mengelola kiriman-kiriman e-mail dalam bentuk folderfolder dan menghapus kiriman-kiriman e-mail yang sudah tidak berguna. Pustakawan generasi digital juga mampu mengelola spam yang masuk.

2. Core Hardware

Pustakawan generasi digital mampu menangani problem hardware yang lebih sulit dari pada pustakawan generasi digital immigrant, misalnya dalam menangani spare part hardware yang rusak.

\section{Core Internet}

Pustakawan generasi digital lebih aktif dan bervarisi dalam menggunakan internet dari pada pustakawan generasi digital immigrant, selain untuk mendukung tugas-tugasnya, pada waktu 
senggang mereka gunakan untuk hiburan dan jejaring sosial, misalnya bermain game, akses YouTube, mendengarkan musik, chatting, facebook, dan sebagainya. Alamat web site yang dikunjungi pustakawan generasi digital juga lebih banyak dari pada pustakawan generasi digital immigrant.

4. Core Operating Systems

Dalam hal Operating System, pustakawan generasi digital dan generasi digital immigrant pada umumnya mempunyai kemampuan yang sama.

5. Core Software

Pustakawan generasi digital lebih banyak menggunakan aplikasi software dari pustakawan generasi digital immigrant. Selain itu apabila ada masalah dengan aplikasi software, pustakawan generasi digital pada umumnya mencoba memperbaiki sendiri dahulu dan apabila tidak bisa kemudian menanyakan ke tim TI lembaganya.

\section{Core Web Tools}

Sebagian besar pustakawan generasi digital sudah mempunyai blog, tetapi jarang di-update. Selain itu pustakawan generasi digital juga lebih aktif dalam menggunakan face book dari pada pustakawan generasi digital immigrant. Pada umumnya pustakawan generasi digital sudah menggunakan file sharing dengan web khusus. Pustakawan generasi digital juga pernah menggunakan web conference dan mengetahui secara teknis.

7. Core Technology System dan Technology Information

Pustakawan generasi digital belajar TI secara otodidak dan pernah mengikuti training. Sebagian besar pustakawan generasi digital mampu mendesain web perpustakaan. Beberapa dari mereka juga mampu melakukan install, konfigurasi, dan pemeliharaan hardware Perpustakaan dengan bantuan tim TI lembaganya.

Dari beberapa kelebihan pustakawan generasi digital dalam bidang TI di atas maka diharapkan akan lebih siap dalam menghadapi generasi digital. Namun demikian pustakawan generasi digital immigrant tetap mempunyai semangat atau motivasi untuk selalu belajar dalam bidang teknologi informasi untuk menghadapi pemustaka generasi digital.

\section{DAFTAR PUSTAKA}

Evilyn, Rika. 2010. "Perpustakaan Siap Saji Untuk Generasi Millennial". Media Informasi: Forum Komunikasi Perpustakaan, Vol. XIX, No. 1. hal: 33-41.

Feredal Library \& Information Center Commite. 2008. Federal Librarian Competencies Oktober 2008. Washington, DC.: FLICC.

Mardianto, Markus. 2010. "Generasi Digital, Siapkah Kita Menghadapinya?”. http://www.kompas.com

Nasution, S. 2003. Metode Penelitian Naturalistik Kualitatif. Ed. Ke-1, Cet. Ke-3. Bandung: Tarsito.

Rivai, H. Veithzal 2009. Manajemen sumber daya manusia untuk perusahaan: dari teori ke praktik. Jakarta: Rajawali Press.

Sukirno. 2004. "Membangun competitive advantage dunia pendidikan melalui teknologi informasi". Jurnal Pendidikan Akuntansi Indonesia, vol. 3 (1), hal.: 86-91.Sumarsono, 2004. Sonny H.M. Metode Riset Sumber Daya Manusia. Yogyakarta: Graha Ilmu.

WebJunction. 2009. Competency Index for the Library Field. Dublin, Ohio: OCLC.

\author{
UCAPAN TERIMA KASIH KEPADA \\ LEMBAGA PENELITIAN \& PENGABDIAN \\ MASYARAKAT (LPPM) UGM YANG TELAH \\ MEMBERIKAN DANA DALAM PENELITIAN \\ INI.
}

